Mr Petar Nikšic, dipl. inž.

\section{Regeneracija rezervnih delova - metode i postupci}

$U$ radu su prikazane opšte i specijalne metode regeneracije. Date su tehničke karakteristike pojedinih metoda regeneracije sa širokom primenom i najkarakterističniji predstavnici oštećenih delova. Posebno je istaknut asortiman delova i sklopova koji se regenerišu.

\section{Uvod}

Tokom eksplaatacije mašina, alata i uređaja, transportnih sredstava, građevinske, medicinske $i$ industrijske opreme; na njihovim sastavnim delovima nastaju različita oštećenja raznolikog položaja, oblika i veličine. Nastanak oštećenja na raznim delovima mašina, uređaja i opreme, dovodi do smanjenja njihovih eksploatacijskih mogućnosti ili do potpune nemogućnosti njihove upotrebe.

Princip obezbeđenja nesmetanog toka proizvodnje, sa što manje prekida, zastoja i otkaza, iziskuje angažovanje skupocene opreme za dijagnostiku, remont i ispitivanje, kojom rukuje posebno obučen stručni kadar; uz korišćenje znatne količine rezervnih delova iz skladišta - što je veoma skupo i nerentabilno.

U toku dugogodišnjeg rada na remontu i održavanju sredstava specijalne namene, Tehnički remonti $\mathrm{Za}$ vod - Cačak je, radi smanjenja troškova na sveukupnom tehničkom održavanju pri remontu sredstava, uveo i razvio posebnu oblast opravke revitalizaciju ili regeneraciju rezervnih delova. Optimizacija zaliha rezervnih delova po asortimanu i količini u skladištima, uvođenje postupka regeneracije delova, uz smanjene zavisnosti od uvoza i proizvođača opreme i sniženje troškova održavanja proizvodne opreme i sredstava je sve više prisutan način organizovanja modernih službi plansko-preventivnog održavanja.

$\mathrm{U}$ ovom radu biće prikazane metode i njihove karakteristike, mogućnosti i postupci regeneracije rezervnih delova $u$ Tehničkom remontnom Zavodu Cačak - radi njihovog prikazivanja potencijalnim korisnicima i proširenja područja primene $u$ današnjim uslovima proizvodnje i remonta opreme i sredstava. Saznanja iz regeneracije sve se više koriste $i$ pri izradi novih delova radi uštede na skupim materijalima ili obradi, kao i na poboljšanju mehaničkih, antifrikcionih, antikorozionih i drugih karakteristika.

\section{Metode regeneracije rezervnih delova}

Pod pojmom regeneracija podrazumeva se sprovođenje niza tehnoloških operacija, čiji rezultat je obnavljanje radne sposobnosti oštećenog dela, vraćanjem njegovog oblika, veličine, dimenzija i željenih kanakteristika na nivo pre početka eksploatacije ili na njegove dozvoljene remontne mere i karakteristike. 
Opšti tehnološki proces regeneracije oštećenih rezervnih delova sastoji se od sledećih operacija: dela;

- čišćenja, pranja i odmašćivanja

- defektacije dela;

- pripreme dela za nanošenje metalnih slojeva;

- nanošenje metalnih slojeva na deo;

- mašinske, termičke, zaštitne i završne obrade dela,

- ispitivanja, kontrole kvaliteta, homologacije, konzervacije i pakovanje.

Sopstvenim razvojem i u saradnji sa nizom inostranih i domaćih firmi, Zavod je usvojio, usavršio i razvio više tehnologija, kojima se oštećeni delovi mogu uspešno regenerisati, uz ispunjenje traženih karakteristika dela $u$ pogledu veka trajanja, pouzdanosti i bezbednosti pri upotrebi. Uzimajući kao osnov princip nanošenja dodatnog materijala na oštećeni deo, klasifikacija metode regeneracije korišćenih $u \mathrm{Za}$ vodu može se shematski prikazati kao na sl. 1.

Tehničke karakteristike metoda regeneracije sa najširom primenom i područje njihove primene sa najkarakterističnijim predstavnicima oštećenih delova prikazani su u tabeli 1 .

Svaka od navedenih metoda regeneracije delova prikazana $u$ tabeli 1 , ima svoje prednosti i nedostatke; tako da je jedan od osnovnih zadataka pri regeneraciji delova izbor optimalne metode, koja ce obezbediti maksimalni vek trajanja dela uz minimalne troškove. $\mathrm{Na}$ izbor optimalne metode regeneracije nekog dela utiče mnoštvo faktora, od kojih su najznačajniji:

- karakteristike oštećenja na delu (položaj, vrsta, veličina);
- radni uslovi dela pri eksploataciji (veličina i vrsta opterećenja, način podmazivanja, karakteristike delova $u$ kontaktu i radne sredine);

- konstrukcijsko-tehnološke karakteristike dela (geometrijski oblik i dimenzije, materijal sa mehaničko-metalografskim osobinama, tehničko stanje i način zaštite, tehnologije izrade);

- tehnološke i mehaničke karakteristike metalnih slojeva nanošenih na oštećenje površine delova, i

- troškovi regeneracije svih metoda regeneracije koje se mogu primeniti za oštećeni deo.

$\mathrm{Na}$ osnovu navedenih faktora, tehnološka služba $u$ Zavodu određuje optimalnu metodu regeneracije sa proračunom očekujućeg veka trajanja dela i cenom regeneracije.

\section{Obezbeđenje kvaliteta i ekonomičnosti regeneracije delova}

Navedene metode regeneracije se primenjuju uz korišćenje savremene opreme i najkvalitetnijih dodatnih materijala svetskih i domaćih proizvođača, kao što su: „METCO«, »WELDSTEEL«, »LINCOLN«, »LOCTITE« - Sjedinjene Države: „CASTOLIN« - Svajcarska, »UTP«, »BOHLER« - Nemačka, »BELZONA«, »METALOCK« - Engleska, itd. Zavod je tokom dugogodišnjeg rada uz razvoj samih metoda nanošenja dodatnih materijala na oštećeni deo, usavršio i nabavio opremu za kompletan tehnološki proces regeneracije delova. Posedujemo savremenu opremu i kadrove za sve tehnološke operacije pripreme delova i za operacije mašinske, termičke, galvanske zaštite i završne obrade delova. 


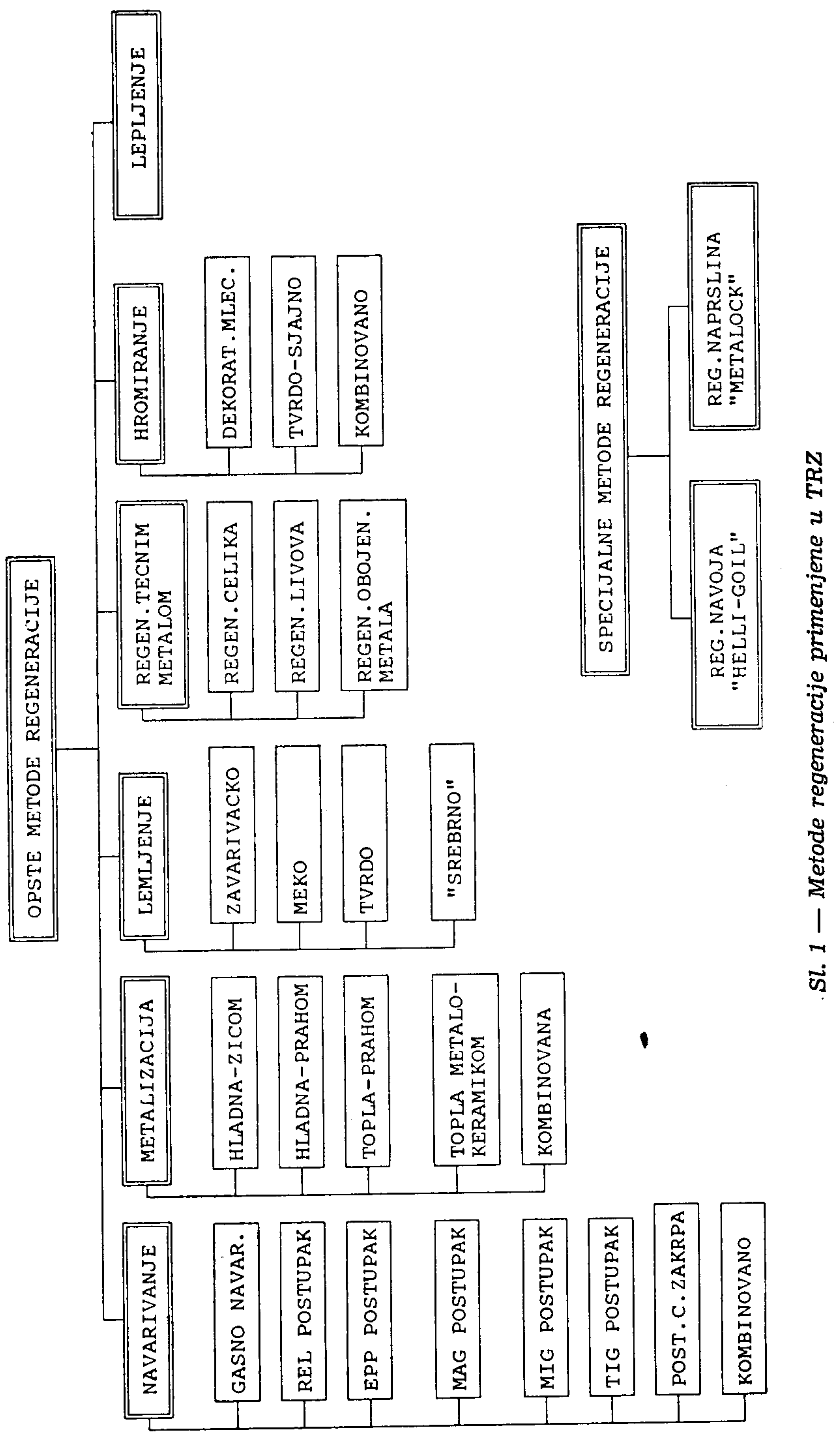




\begin{tabular}{|c|c|c|c|c|}
\hline \multirow{2}{*}{$\begin{array}{l}\text { Red. } \\
\text { br. }\end{array}$} & \multirow{2}{*}{$\begin{array}{l}\text { Metoda } \\
\text { regeneracije }\end{array}$} & \multicolumn{3}{|c|}{ Tehničke karakteristike i područje primene } \\
\hline & & $\begin{array}{c}\text { Materijal } \\
\text { oštećenog dela }\end{array}$ & Oblast primene & $\begin{array}{l}\text { Karakteristični } \\
\text { predstavnik }\end{array}$ \\
\hline 1 & 2 & 3 & 4 & 5 \\
\hline 1. & $\begin{array}{l}\text { Ručno elektroluč- } \\
\text { no navarivanje } \\
\text { (REL postupak) }\end{array}$ & $\begin{aligned} \text { - čelici svih } \\
\text { kvaliteta, } \\
\text { - čelični i speci- } \\
\text { jalni liv } \\
\text { - sivi liv } \\
\text { - obojeni metali } \\
\text { i njihove legure }\end{aligned}$ & $\begin{array}{l}\text { - navarivanje č- } \\
\text { ličnih i ostalih } \\
\text { materijala; slo- } \\
\text { jem debljine } \\
0,5-20 \mathrm{~mm} \text { i } \\
\text { tvrdoće 18-65 } \\
\text { HRC } \\
\text { - međusobno za- } \\
\text { varivanje čelika } \\
\text { različitog kva- } \\
\text { liteta } \\
\text { - oplemenjivanje } \\
\text { radnih površina } \\
\text { konstrukcionih } \\
\text { i drugih čelika } \\
\text { (zubi bagera, } \\
\text { delovi rudarske } \\
\text { građevinske i } \\
\text { prehrambene } \\
\text { opreme) }\end{array}$ & $\begin{array}{l}\text { - kućišta, blokovi } \\
\text { i poklopci mo- } \\
\text { tora SUS snage } \\
0,5-1200 \mathrm{~kW} \\
\text { - glave motora } \\
\text { SUS (sedište } \\
\text { ventila) } \\
\text { - zubi zupčanika } \\
\text { - ožljebljenja na } \\
\text { vratilima preč- } \\
\text { nika do } 300 \mathrm{~mm} \\
\text { i duž. do } 2000 \\
\text { mm } \\
\text { - rukavci oso- } \\
\text { vina i radnih } \\
\text { valjaka prečni- } \\
\text { ka do } 1100 \mathrm{~mm} \\
\text { i dužine do } 3500 \\
\text { mm. } \\
\text { - alati za defor- } \\
\text { maciju i pribori }\end{array}$ \\
\hline 2. & $\begin{array}{l}\text { Elektrolučno na- } \\
\text { varivanje pod pra- } \\
\text { hom (EPP postu- } \\
\text { pak) }\end{array}$ & $\begin{array}{l}\text { - nelegirani i ni- } \\
\text { skolegir. celici } \\
\text { - niskougljenični } \\
\text { čelici sa manje } \\
\text { od } 0,34^{\circ} \% \text { uglje- } \\
\text { nika }\end{array}$ & $\begin{array}{l}\text { - navarivanje } \\
\text { masivnih pred- } \\
\text { meta prečnika } \\
\text { do } 700 \mathrm{~mm} \mathrm{i} \\
\text { dužine do } 4000 \\
\text { mm, slojem de- } \\
\text { bljine do } 10 \\
\text { mm, tvrdođe od } \\
14-40 \text { HRC } \\
\text { - zavarivanje } \\
\text { brodskih limova } \\
\text { i novih cevi de- } \\
\text { bljine od } 5 \mathrm{~mm}\end{array}$ & $\begin{array}{l}\text { - laktaste osovine } \\
\text { - doboši kvačila i } \\
\text { kočnica } \\
\text { - diskovi prednjih } \\
\text { i zadnjih točko- } \\
\text { va } \\
\text { - kućišta ležajeva } \\
\text { - ozubljeni i ož- } \\
\text { ljebljeni delovi } \\
\text { vratila } \\
\text { - spojnice i spoj- } \\
\text { ničko vratilo }\end{array}$ \\
\hline 3. & $\begin{array}{l}\text { Elektrolučno na- } \\
\text { varivanje u zaštiti } \\
\text { aktivnog gasa } \mathrm{CO}_{2} \\
\text { (MAG postupak) }\end{array}$ & $\begin{array}{l}\text { - nelegirani i ni- } \\
\text { skolegirani če- } \\
\text { lici debljine do } \\
10 \mathrm{~mm} \\
\text { - čelici za ko- } \\
\text { tlovske limove } \\
\text { i cevi tvrdoće } \\
\text { do } 60 \mathrm{dN} / \mathrm{mm}^{2} \\
\text { - poboljšani i } \\
\text { temperaturno } \\
\text { otporni čelici }\end{array}$ & $\begin{array}{l}\text { - navarivanje i } \\
\text { zavarivanje ra- } \\
\text { znih celičnih } \\
\text { konstrukcija } \\
\text { (opčate, kotlovi, } \\
\text { toplovodi,...) } \\
\text { gde se zahteva } \\
\text { mala deforma- } \\
\text { cija delova }\end{array}$ & $\begin{array}{l}\text { - kotlovi i toplo- } \\
\text { vodi } \\
\text { - rukavci na oso- } \\
\text { vinama i rad- } \\
\text { nim valjcima } \\
\text { - gnezda ležaja } \\
\text { - rukavci osovina } \\
\text { i vratila i kom- } \\
\text { presora prečni- } \\
\text { ka do } 700 \mathrm{~mm} \\
\text { i dužine do } 3500 \\
\text { mm }\end{array}$ \\
\hline
\end{tabular}




\begin{tabular}{|c|c|c|c|c|}
\hline \multirow[b]{2}{*}{$\begin{array}{c}\text { Red. } \\
\text { br. }\end{array}$} & \multirow{2}{*}{$\begin{array}{l}\text { Metoda } \\
\text { regeneracije }\end{array}$} & \multicolumn{3}{|c|}{ Tehničke karakteristike i područje primene } \\
\hline & & $\begin{array}{c}\text { Materijal } \\
\text { oštećenog dela }\end{array}$ & Oblast primene & $\begin{array}{l}\text { Karakteristični } \\
\text { predstavnik }\end{array}$ \\
\hline 1 & 2 & 3 & 4 & 5 \\
\hline 4. & $\begin{array}{l}\text { Elektrolučno na- } \\
\text { varivanje u zaštiti } \\
\text { inertnog gasa or- } \\
\text { gana (MTG po- } \\
\text { stupak) }\end{array}$ & $\begin{array}{l}\text { - aluminijum, } \\
\text { bakar, i njiho- } \\
\text { ve legure deb- } \\
\text { ljine do } 20 \mathrm{~mm} \\
\text { - visokolegirani i } \\
\text { nerđajući celici } \\
\text { debljine do } \\
10 \mathrm{~mm}\end{array}$ & $\begin{array}{l}\text { - navarivanje de- } \\
\text { lova tipa poklo- } \\
\text { paca, kućišta } \\
\text { itd., slojem de- } \\
\text { bljine do } 20 \mathrm{~mm} \\
\text { - navarivanje i } \\
\text { zavarivanje } \\
\text { aluminijumskih } \\
\text { i bakarnih legu- } \\
\text { ra sa sadržajem } \\
\text { silicijuma, mon- } \\
\text { taža cinka, olo- } \\
\text { va itd. }\end{array}$ & $\begin{array}{l}\text { - glave i korita } \\
\text { motora SUS od } \\
\text { aluminijuma i } \\
\text { njegovih legura } \\
\text { - kućišta ležajeva }\end{array}$ \\
\hline 5. & $\begin{array}{l}\text { Elektrolučno na- } \\
\text { varivanje u zastiti } \\
\text { inertnog gasa or- } \\
\text { gana (TIG postu- } \\
\text { pak) }\end{array}$ & $\begin{array}{l}\text { - Al, Cu, Mg, Ni, } \\
\text { Ti, Zn, Be i nji- } \\
\text { hove legure de- } \\
\text { bljine vece od } \\
0,5 \mathrm{~mm} \\
\text { - ugljenični i le- } \\
\text { girani čelici de- } \\
\text { bljine veće od } \\
0,5 \mathrm{~mm}\end{array}$ & $\begin{array}{l}\text { - navarivanje ra- } \\
\text { znih mašinskih } \\
\text { delova od teško } \\
\text { zavarivanih ce- } \\
\text { lika i visokole- } \\
\text { giranih čelika } \\
\text { - navarivanje } \\
\text { obojenih legura } \\
\text { - navarivanje } \\
\text { bronze i mesin- } \\
\text { ga na celik }\end{array}$ & $\begin{array}{l}\text { - alati od pro- } \\
\text { hronskog i br- } \\
\text { zoreznog celika } \\
\text { - karteri i delovi } \\
\text { od Al legura } \\
\text { - klipovi hidra- } \\
\text { uličnih sistema }\end{array}$ \\
\hline 6. & $\begin{array}{l}\text { Hlandna gasna } \\
\text { metalizacija žicom }\end{array}$ & $\begin{array}{l}\text { - Celici svih vrsta } \\
\text { - celicni, sivi i } \\
\text { specijalni liv } \\
\text { - obojeni metail i } \\
\text { njihove legure }\end{array}$ & $\begin{array}{l}\text { - rukavci osovina } \\
\text { prečnika do } \\
1000 \mathrm{~mm} \text { i du- } \\
\text { žine do } 3500 \\
\text { mm tvrdoć od } \\
14-50 \text { HRC i } \\
\text { debljine sloja } \\
0,25-3 \text { lm } \\
\text { - vučni bubnjevi } \\
\text { za izvlačenje } \\
\text { bakarne žice } \\
\text { prečnika do } \\
1200 \text { mm i du- } \\
\text { žine do } 2500 \text { mm } \\
\text { - dve vrste ruka- } \\
\text { vaca za ležaje- } \\
\text { ve, caure, kli- } \\
\text { povi,... } \\
\text { nanošenje na } \\
\text { osnovni materi- } \\
\text { jal sloja mate- } \\
\text { rijala razlicite } \\
\text { vrste }\end{array}$ & $\begin{array}{l}\text { - gnezda ležaja } \\
\text { na blokovima } \\
\text { motora SUS } \\
\text { - otvori u kući- } \\
\text { stima različitog } \\
\text { tipa } \\
\text { - vučni bubnjevi } \\
\text { za žicu } \\
\text { - ležajevi kolena- } \\
\text { stih osovina } \\
\text { prečnika do } 200 \\
\text { mm i dužine do } \\
2100 \text { mm } \\
\text { - nanošenje bron- } \\
\text { ze i mesinga na } \\
\text { klipove i klip- } \\
\text { njač hidrauli- } \\
\text { čnih sistema } \\
\text { prečnika do } \\
300 \text { mm i duži- } \\
\text { ne do } 2600 \text { mm }\end{array}$ \\
\hline
\end{tabular}




\begin{tabular}{|c|c|c|c|c|}
\hline \multirow{2}{*}{$\begin{array}{l}\text { Red. } \\
\text { br. }\end{array}$} & \multirow{2}{*}{$\begin{array}{l}\text { Metoda } \\
\text { regeneracije }\end{array}$} & \multicolumn{3}{|c|}{ Tehničke karakteristike i područje primene } \\
\hline & & $\begin{array}{c}\text { Materijal } \\
\text { oštećenog dela }\end{array}$ & Oblast primene & $\begin{array}{l}\text { Karakteristični } \\
\text { predstavnik }\end{array}$ \\
\hline 1 & 2 & 3 & 4 & 5 \\
\hline 7. & $\begin{array}{l}\text { Hladna gasna } \\
\text { metalizacija pro- } \\
\text { hrom }\end{array}$ & $\begin{array}{l}\text { - razni konstruk- } \\
\text { cioni čelici } \\
\text { - čelični, sivi i } \\
\text { specijalni liv }\end{array}$ & $\begin{array}{l}\text { - rukavci kolena- } \\
\text { stih vratila } \\
\text { kompresora pre- } \\
\text { čnika do } 600 \\
\text { mm i dužine do } \\
2100 \text { mm, slojem } \\
\text { debljine 0,25- } \\
\text {-1,5 mm i tvr- } \\
\text { doće do } \\
400 H V 10 \\
\text { - pokretni i kliz- } \\
\text { ni spojevi ma- } \\
\text { šinskih delova } \\
\text { - hidraulični kli- } \\
\text { povi }\end{array}$ & $\begin{array}{l}\text { - kolenasto vrati- } \\
\text { lo kompresora i } \\
\text { motora SUS } \\
\text { - rukavci osovina } \\
\text { i vratila } \\
\text { - valjci u papir- } \\
\text { noj i tekstilnoj } \\
\text { industriji preč- } \\
\text { nika do 700 mm } \\
\text { i dužine do } \\
\text { 3500 mm }\end{array}$ \\
\hline 8. & $\begin{array}{l}\text { Topla gasna } \\
\text { metalizacija pra- } \\
\text { hom }\end{array}$ & $\begin{array}{l}\text { - razni konstruk- } \\
\text { cioni čelici, } \\
\text { - otkovci od svih } \\
\text { materijala }\end{array}$ & $\begin{array}{l}\text { - metalizacija bre- } \\
\text { gastih vratila } \\
\text { prečnika do } 200 \\
\text { mm i dužine do } \\
1500 \text { mm, slo- } \\
\text { jem od 0,1-1,5 } \\
\text { mm tvrdoće do } \\
65 \text { HRC } \\
\text { - nabacivanje } \\
\text { bronze na celike } \\
\text { - tvrdi nanosi na } \\
\text { nerđajućim ce- } \\
\text { licima i livenom } \\
\text { gvožđu } \\
\text { - reparacija ce-- } \\
\text { mentiranih i } \\
\text { kaljenih povr- } \\
\text { sina }\end{array}$ & $\begin{array}{l}\text { - bregasta vratila } \\
\text { motora suS } \\
\text { - puževi, ekstru- } \\
\text { deri za gumu i } \\
\text { plastiku i za- } \\
\text { vojne površine } \\
\text { - izduvne grane i } \\
\text { blokovi motora } \\
\text { - zubi zupcanika }\end{array}$ \\
\hline 9. & $\begin{array}{l}\text { Topla gasna } \\
\text { metalizacija meta- } \\
\text { lokeramikom }\end{array}$ & $\begin{array}{l}\text { - čelici svih vrsta } \\
\text { - odlivci od čli- } \\
\text { ka, sivog i spe- } \\
\text { cijalnog liva }\end{array}$ & $\begin{array}{l}\text { - oplemenjivanje } \\
\text { radnih habaju- } \\
\text { ćih površina na } \\
\text { raznim delovi- } \\
\text { ma } \\
\text { - zaštita delova } \\
\text { od korozije u } \\
\text { agresivnoj, ki- } \\
\text { seloj i baznoj } \\
\text { sredini }\end{array}$ & $\begin{array}{l}\text { - vratila muljnih } \\
\text { i potapajućih } \\
\text { pumpi } \\
\text { - lopatice venti- } \\
\text { latora } \\
\text { - potisne ploce } \\
\text { - specijalne for- } \\
\text { me alata za ob- } \\
\text { radu deformaci- } \\
\text { jom }\end{array}$ \\
\hline
\end{tabular}




\begin{tabular}{|c|c|c|c|c|}
\hline \multirow[b]{2}{*}{$\begin{array}{c}\text { Red. } \\
\text { br. }\end{array}$} & \multirow[b]{2}{*}{$\begin{array}{l}\text { Metoda } \\
\text { regeneracije }\end{array}$} & \multicolumn{3}{|c|}{ Tehnicke karakteristike i područje primene } \\
\hline & & $\begin{array}{l}\text { Materijal } \\
\text { oštećenog dela }\end{array}$ & Oblast primene & $\begin{array}{c}\text { Karakteristicni } \\
\text { predstavnik }\end{array}$ \\
\hline 1 & 2 & 3 & 4 & 5 \\
\hline 10. & $\begin{array}{l}\text { Regeneracija teč- } \\
\text { nim metalom }\end{array}$ & $\begin{array}{l}\text { - sve vrste čelika } \\
\text { - čelični i sivi liv } \\
\text { - sve vrste oboje- } \\
\text { nih metala i } \\
\text { njihovih legura }\end{array}$ & $\begin{array}{l}\text { - popravka ošte- } \\
\text { ćenja usled is- } \\
\text { trošenosti, pu- } \\
\text { kotina, loma na } \\
\text { blokovima mo- } \\
\text { tora, kućištima } \\
\text { prenosnika, } \\
\text { vratilima, kli- } \\
\text { povima } \\
\text { - popravka ošte- } \\
\text { cenja usled ko- } \\
\text { rozije i kovita- } \\
\text { cije }\end{array}$ & $\begin{array}{l}\text { - rukavci osovina } \\
\text { i vratila } \\
\text { - pukotine na } \\
\text { blokovima mo- } \\
\text { tora } \\
\text { - klipovi, cilndri } \\
\text { - radna kola } \\
\text { pumpi }\end{array}$ \\
\hline 11. & $\begin{array}{l}\text { Tvrdo sjajno } \\
\text { hromiranje }\end{array}$ & $\begin{array}{l}\text { - razni konstruk- } \\
\text { cioni čelici tvr- } \\
\text { doće do } 50 \mathrm{HRC} \\
\text { - čelični, sivi i } \\
\text { specijalni liv }\end{array}$ & $\begin{array}{l}\text { - klipnjače i ci- } \\
\text { lindri u hidra- } \\
\text { uličnim siste- } \\
\text { mima prečnika } \\
\text { do } 500 \mathrm{~mm} \mathrm{i} \\
\text { dužine do } 2600 \\
\text { mm } \\
\text { - rukavci ležaja } \\
\text { na osovinama, } \\
\text { slojem 0,05-0,5 } \\
\text { mm i tvrdocee } \\
\text { do } 58 \text { HRC } \\
\text { - košuljice moto- } \\
\text { ra SUS } \\
\text { - složene forme } \\
\text { alata za plasti- } \\
\text { ku i vulkaniza- } \\
\text { ciju }\end{array}$ & $\begin{array}{l}\text { - klipnjače, klipo- } \\
\text { vi i cilindri hi- } \\
\text { dro-pneumat- } \\
\text { skih sistema } \\
\text { - osovine klipova } \\
\text { motora sUS } \\
\text { - radne površine } \\
\text { valjaka u grafi- } \\
\text { čkoj industriji } \\
\text { - rukavci brega- } \\
\text { stih osovina i } \\
\text { radilica }\end{array}$ \\
\hline
\end{tabular}

Zavod ima savremeno opremljene laboratorije za određivanje i kontrolu hemijskog sastava, mehaničkih karakteristika i metalografskih osobina osnovnog materijala dela i nanošenog metalnog sloja. Posebna pažnja je posvećena defektoskopskim ispitivanjima bez razaranja, tako da se u Zavodu primenjuju enegrantska, magnetna, ultrazvučna i rendgenska kontrola kvaliteta regenerisanih delova, opremom za ispitivanje bez razranja rukuju naši specijalisti koji poseduju domaće i međunarodne ateste i ovlašćenja.
$\mathrm{Za}$ sve postupke regeneracije $\mathrm{Za}-$ vod izdaje odgovarajuće garancije (ateste, sertifikate i sl.).

Ekonomičnost regeneracije oštećenih delova, u uslovima moguće izrade ili nabavke novog dela, ocenjuje se pomoću koeficijenta cene $\left(\mathrm{K}_{\mathrm{c}}\right)$ koji se računa kao

$$
\mathrm{K}_{\mathrm{c}}=\frac{\mathrm{Cn}-\mathrm{Cr}}{\mathrm{Cn}}
$$

gde je:

Cn - cena izrade ili nabavke novog dela i

$\mathrm{Cr}$ - cena regeneracije aštećenog istog takvog dela. 
Smatra se ekonomski opravdana regeneracija ako je $\mathrm{K}_{\mathrm{c}}>0,4$. Zavodska iskustva pokazuju da je $\mathrm{Kc}=0,4-0,9$ sto znači da se cena regenerisanog oštećenog dela kreće $10 \%$ do $60 \%$ od cene novog istog takvog dela.

Opravdanost i ekonomičnost regeneracije oštećenog dela utvrđujemo najcešce sagledavanjem sledećih pokazatelja:

- odnosa cene novog i regenerisanog dela; dela;

- mogućnosti obezbeđenja novog ciju dela, i

- pouzdanosti veka trajanja regenerisanog dela $u$ odnosu na novi deo.

O ekonomskoj opravdanosti regeneracije upoznajemo Vas pri razmatranju mogučnosti regeneracije i navedenih pokazatelja, na bazi Vašeg zahteva.

\section{Asortiman delova i sklopova koji se regenerišu}

Asortiman delova i sklopova koji se regenerišu u Zavodu je veoma raznovrstan, počev od vitalnih do najjednostavnijih delova $u$ određenim sklopovima i agregatima mašina i opreme, i može se podeliti u sledeće karakteristične grupe:

- motori SUS (blok, korito ulja, kolenasto i bregasto vratilo klipnjače, klipovi, osovine, čaure, ....);

- menjači i multiplikatori stepena prenosa (zupčanici, sinhrone poluge, vratila, osovine, doboši, čaše, ručice, ...);

- sistemi za upravljanje i zaustavljanje (pogonski točkovi, laktaste osovine i torziona vratila, poluge, čaure, doboši, kočione trake, ...);
- ventilatori (osovine, rotori, lopatice, diskovi, ....);

- hidraulični i pneumatski sistemi (klipovi, klipnjače, cilindri, ventili, razvodnici, pumpe, ...);

- alati za: vulkanizaciju, plastiku, obradu deformisanjem, kovanje i livenje;

- valjci u papirnoj, grafičkoj industriji i u željezarama;

-- delovi mašina alatki, presa, specijalnih mašina i uređaja;

- delovi opreme $u$ procesnoj industriji, farmaceutskoj i hemijskoj industriji;

- delovi građevinskih i rudarskih mašina (zubi bagera, kašike utovarivača, raonici, članci i osovinice guseničnog platna, zupčasti točkovi, ...).

Pregled najkarakterističnijih delova sa najčešćim oštećenjima prikazan je u tabeli 2 (str. 26-30).

\section{Zaključak}

Mogućnosti regeneracije delova i sklopova metodama koje se izvode $u$ Zavodu su veoma široke, tako da skoro nema oblasti svakodnevne proizvodnje ili održavanja u kojoj se neka od registrovanih metoda ne može primeniti.

U Zavodu se trenutno planira i radi na uvođenju novih metoda kao što su:

- plazma tehnologija;

- mrežasto hromiranje;

- hemijska prevlaka nikla po KANIGEN-B postupku; nje;

- lasersko površinsko otvrđava-

- jonska implantacija površine metala, i

- prevlačenje metala postupcima PVD $\vdots$ CVD. 


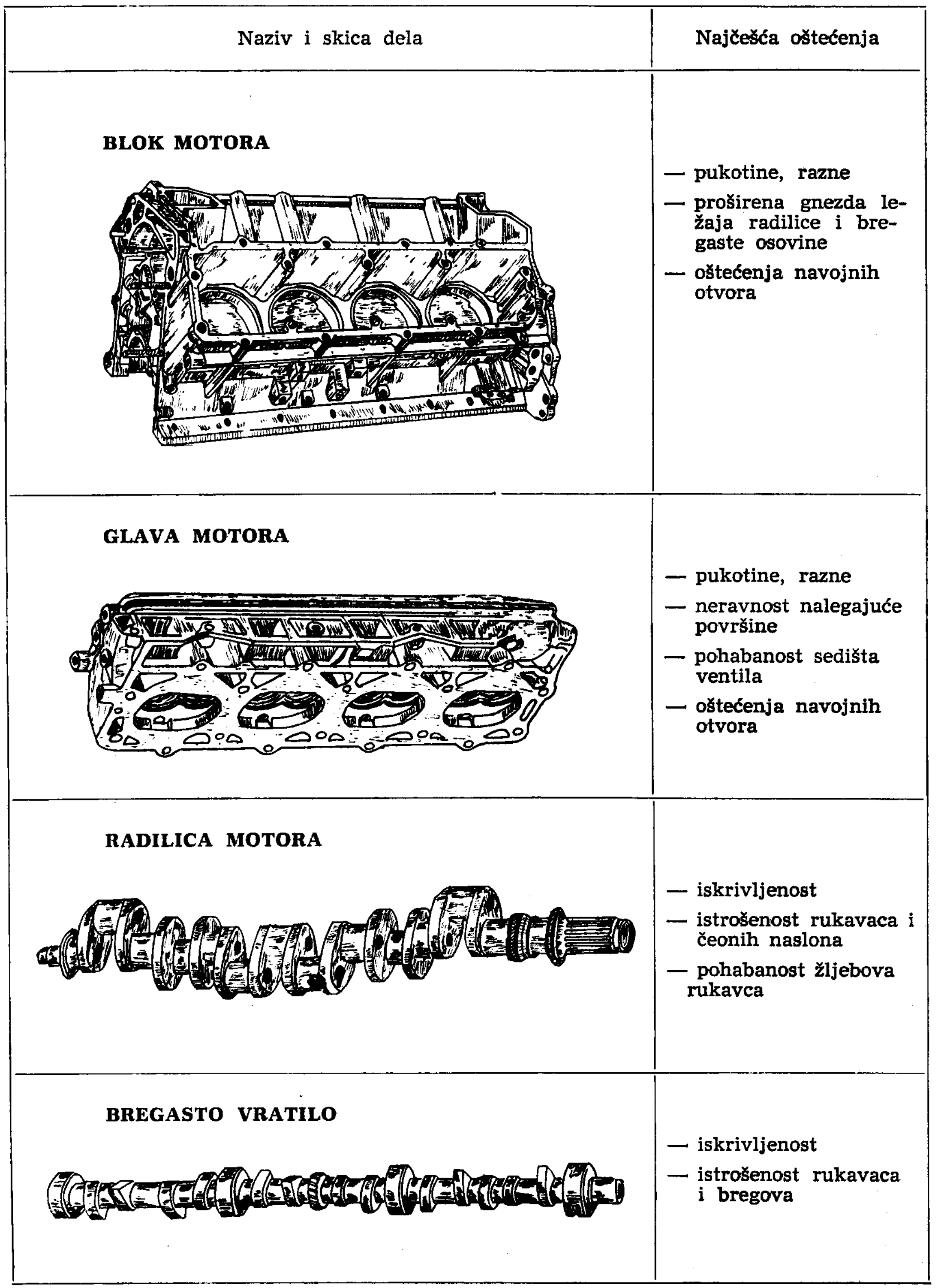




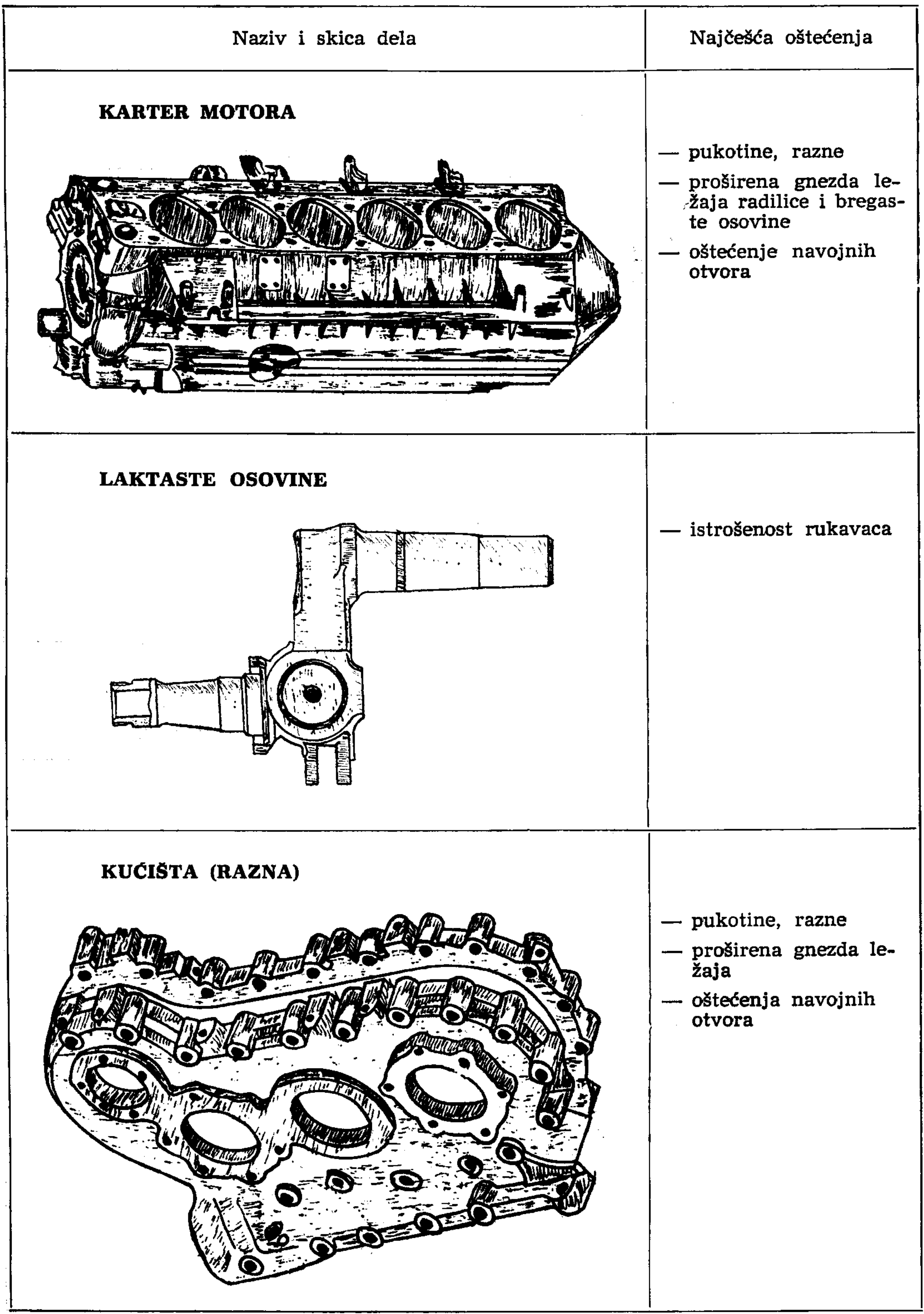




\section{KUCISTA (RAZNA)}

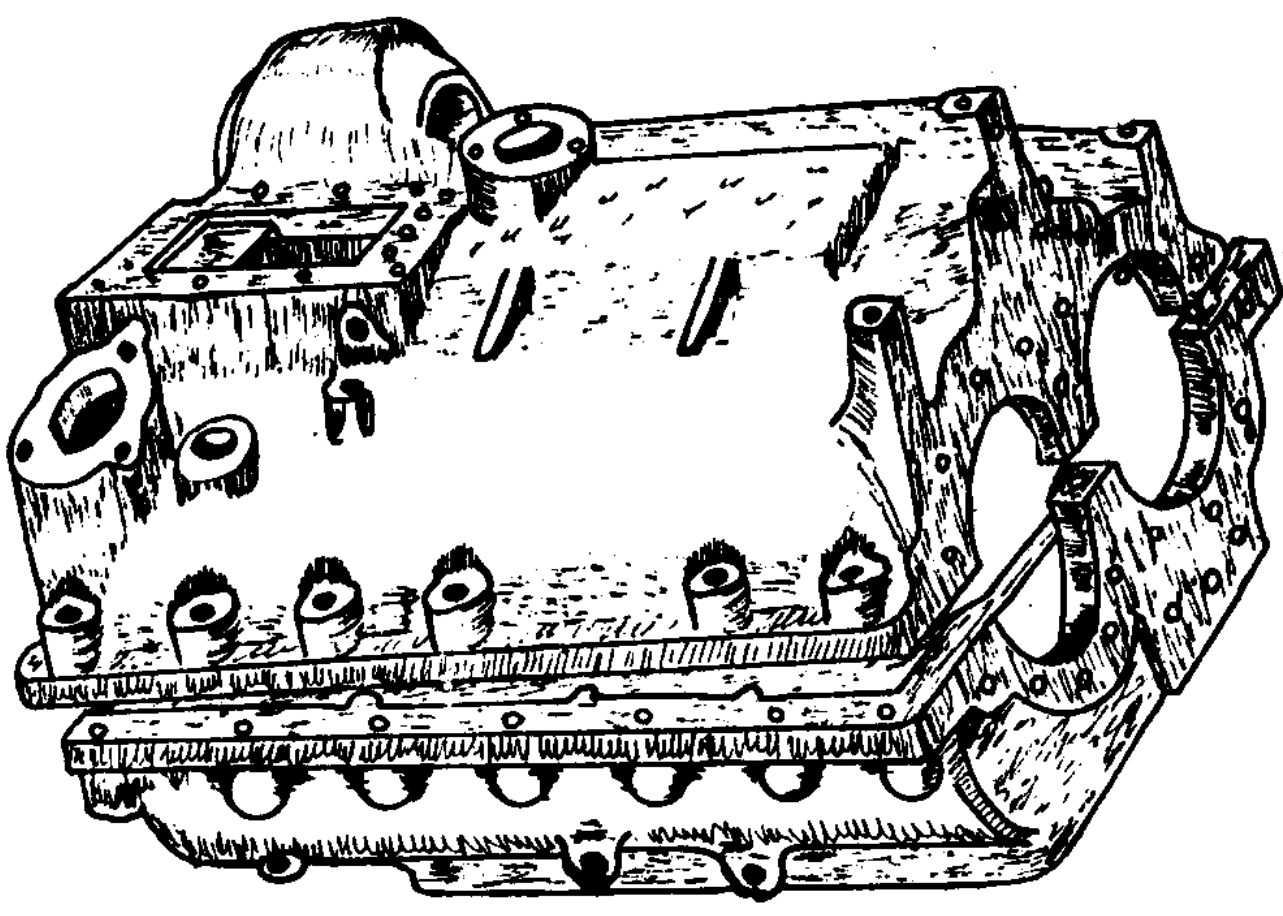

- pukotine, razne

- proširena gnezda ležaja

- ostećenja navojnih otvora
POGONSKA VRATILA

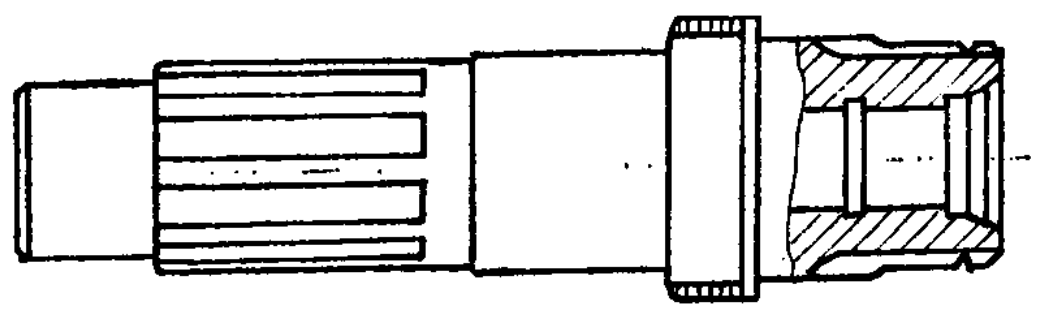

SPOJNIČKA VRATILA

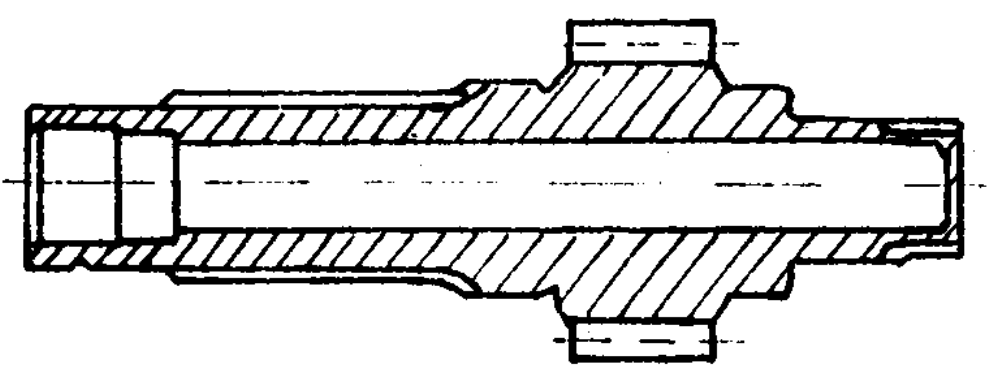

- iskrivljenost

- pohabanost rukavaca i žljebova

- pohabanost žljebova

— iskrivljenost 


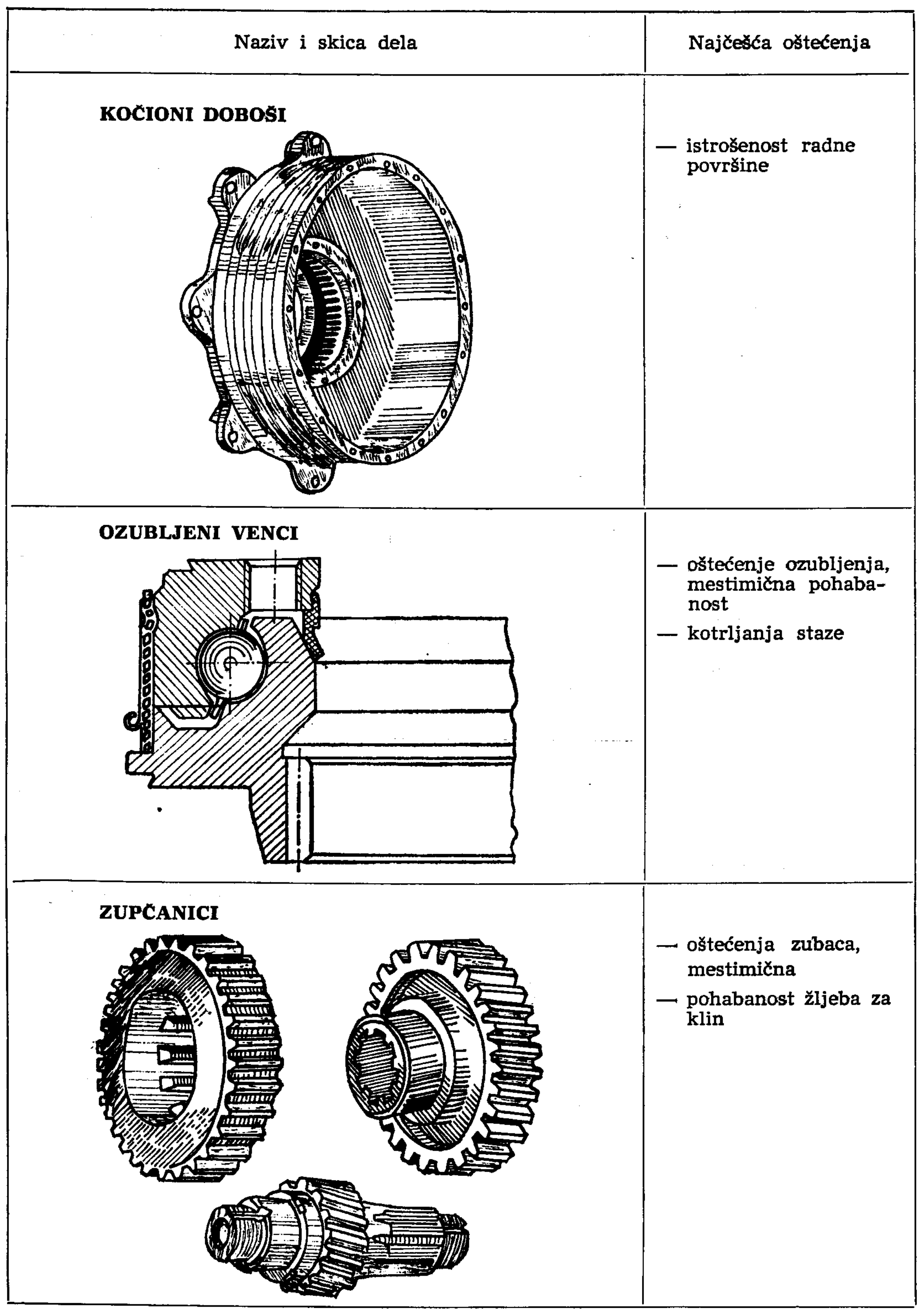




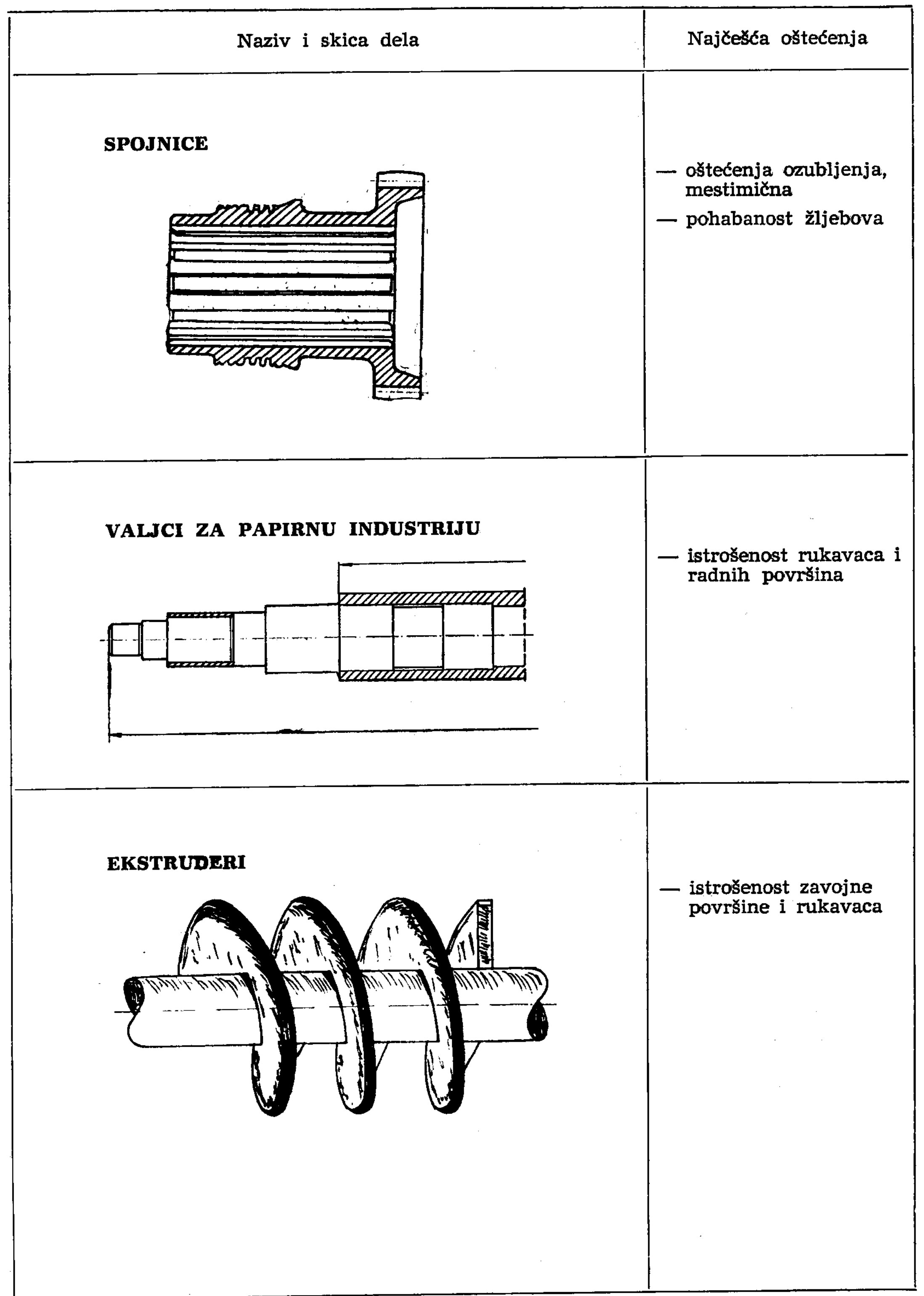


[1] M. A. Elizavetin, E. A. Satelf Tehnologiceskle sposobi povišenia dolgovečnostl mašink, Mašinostroenie, Moskva, 1969. god.;

[2] G. L. Petrov >Teorija svoročnih procesov« Mašinostroenie Moskva, 1977. god.;

[3] z. Avramovic, D. Jovanovic sTerotehnologija u industriji cellkax, Naučna knjiga Beograd 1988. god.;

[4] V. A. Vinokurov sSvarocnle deforma il 1 neprjaženljak, Mašlnostroenle, Moskva, 1978. g.;
[5] Standardi: JUS, DIN, GOST, ISO.

[6] DVS - Merkblatt-1.

[7] Prospektni i propagandni materijal firmi: CASTOLIN, METCO, WELDSTEEL, LOCTITE, LINCOLIN, UTP, BOHLER, BELZONA, METALOCK, OERLIKON, YUWELD, FEP.

[8] Upustva, interni standardi i katalozi Tehnickog Remontnog Zavoda Cačak. 